\title{
GCU
}

Glasgow Caledonian

University

University for the Common Good

\section{Understanding the parkrun community: sacred Saturdays and organic solidarity of parkrunners}

Bowness, James; Tulle, Emmanuelle; McKendrick, John

Published in:

European Journal for Sport and Society

DOI:

$10.1080 / 16138171.2020 .1792113$

Publication date:

2020

Document Version

Author accepted manuscript

Link to publication in ResearchOnline

Citation for published version (Harvard):

Bowness, J, Tulle, E \& McKendrick, J 2020, 'Understanding the parkrun community: sacred Saturdays and organic solidarity of parkrunners', European Journal for Sport and Society, vol. 18, no. 1, pp. 44-63.

https://doi.org/10.1080/16138171.2020.1792113

\section{General rights}

Copyright and moral rights for the publications made accessible in the public portal are retained by the authors and/or other copyright owners and it is a condition of accessing publications that users recognise and abide by the legal requirements associated with these rights.

Take down policy

If you believe that this document breaches copyright please view our takedown policy at https://edshare.gcu.ac.uk/id/eprint/5179 for details

of how to contact us. 
This is a pre-publication version of the paper. This paper was accepted for publication on June $24^{\text {th }}$ 2020. More information about the journal can be accessed here.

Bowness, J., Tulle, E. and McKendrick, J.H (forthcoming) Understanding the parkrun community; sacred Saturdays and organic solidarity of parkrunners, European Journal for Sport and Society

\section{Understanding the parkrun community; sacred Saturdays and organic solidarity of parkrunners}

\section{Abstract}

This article focuses on parkrun, the multi-site weekly timed $5 \mathrm{~km}$ run, which operates around the world. Using Durkheim's work on community, we use qualitative data from a survey of over 8000 parkrunners to make sense of the parkrun community. We argue that parkrun allows for an organic solidarity that celebrates the various moral rationales for participation. We suggest that this organic solidarity produces a collective effervescence that enables parkrunners to think of themselves as part of something bigger than their sporting/health projects. Following Durkheim's ambivalence, we argue that parkrun's collective effervescence may be a double-edged sword. It may make a novel impact on public health by facilitating an increase in physical activity levels amongst previously inactive indviduals, yet it may also reinforce the exclusion of those who perceive themselves to be outsiders to the parkrun community. 


\section{Introduction}

Parkrun is a free, timed, $5 \mathrm{~km}$ run that takes place in parks around the world every Saturday morning. Participants register online, print off a barcode, run/walk the $5 \mathrm{~km}$ course, and scan their barcode at the finish line to register completion. Thirteen athletes and five volunteers participated in the first parkrun event, which took place in 2004 within the grounds of Bushy Park in London (Chakrabortty, 2018). By June 2019, typically between 125,000 and 150,000 participants were taking part in parkrun events each week across the United Kingdom (UK) (parkrun, 2019), rising to 250,000 on occasion (Ingle, 2018). By the end of June 2019, parkrun had surpassed 50 million completed runs in its 15-year history (parkrun, 2019). Outside of the UK, parkrun events take place in Oceania, Asia, North America, Africa and other parts of Europe.

Parkrun receives funding from corporate sponsors and quasi-autonomous non-governmental organisations, such as Sport England, which ensures that parkrun remains a fee-free event (parkrun, 2019). Each event also relies upon a significant number of volunteers, who are often participants who miss the run for that week. As of 2018, there were 117,000 registered volunteers within the UK, with 375,000 globally (Reece et al., 2018). In attempting to appeal to a mass audience, parkrun claims that it is a run and is 'not a race' (Darby, 2016). However, parkrun records times and positions, and course records are maintained. Participants possess a wide range of abilities, from the male record holder, two-time Olympian Andy Baddeley, to those who were formerly sedentary and inactive. Since its inception, the average time of parkrun completion has increased, suggesting that the proportion of parkrunners coming from non-athletic (or even inactive or sedentary) backgrounds is growing (Reece et al., 2018).

Parkrun promotes itself as a movement and a family with the mission of targeting and including previously less active population groups to address contemporary public health 
problems such as obesity and cardiovascular disease. Our paper is designed to explore what attracts and binds participants to the parkrun 'movement' and whether it acts as a community that normalises physical activity in neoliberal society. To do so, we apply the conceptual tools of Emile Durkheim to understand the parkrun community. As parkrun has elsewhere been conceived as a community (Hindley, 2018; Sharman, Nash and Cleland, 2019 ), we will first turn to a review of media coverage and research literature on the parkrun phenomenon.

\section{Parkrun: media and academic research}

Print and television media coverage of parkrun has been overwhelmingly positive, littered with headlines such as 'how parkrun's 13 became 5 million and changed weekends forever' (Ingle, 2018); 'Forget profit. It's love and fun that drives innovations like Parkrun' (Chakrabortty, 2018); and 'Parkrun (sic) \& the NHS: a mutual cause for celebration' (Dickenson, 2018). Aditya Chakrabortty (2018) quotes one parkrunner who presents parkrun as offering a solution to the perceived social problems of contemporary Britain, a narrative often found in print media accounts of parkrun:

"It is the new church," says Karen Weir, who started the Richmond parkrun in 2006. The former City management consultant would give up 10 hours a week just to ensure Saturdays went smoothly for everyone else. "The idea of the community has broken down. People don't go to church anymore. But here, you come together with a load of people - and you feel embedded in the local area".

Aside from reproducing narratives that assume Britain is in the midst of social breakdown, media coverage has also focused upon the public health benefits parkrun may provide for country with continued concerns around obesity. The role of inclusive communities is prevalent here and, in this regard, media coverage and academic research have framed parkrun in similar ways. The earliest study on parkrun came from Stevinson and Hickson 
(2013). They profiled the parkrunning community, finding that most parkrunners were men and between 35 and 54 years of age. They also found that one-quarter of participants had not been runners before beginning parkrun. The inclusion of non-runners, older adults, overweight individuals, and women, led them to conclude that this was a sporting modality that was inclusive and effective at reaching historically excluded populations (Stevinson and Hickson, 2013). Elsewhere, Grunseit, Richards and Merom (2018) found an an association between parkrun participation and subjective improvements in physical and mental wellbeing, with men attributing this to the community connectedness of parkrun. Morris and Scott (2019) also found that parkrun may be a refuge for those with a history of mental health problems.

Research has also examined parkrun's popularity and its ability to encourage and maintain the participation of those who were previously inactive. The qualitative work of Stevinson, Wiltshire and Hickson (2015) suggests that reciprocity and freedom are two essential qualities that keep people parkrunning. Reciprocity is present in parkrun's ability to provide both competition and volunteering opportunities, with Stevinson et al. (2015, p173) arguing that the event allows for 'giving' and 'gaining'. The volunteering, encouragement and fundraising of participants exemplified giving, while gains related to the perceived health benefits and performance enhancement. The theme of freedom related to accessibility and the inclusivity that parkrun affords, generating a distinctly different environment to that of other mainstream physical activities.

Wiltshire and Stevinson (2018) look closely at individual parkrunners' social networks to understand disparities in parkrun participation which mirror broader social inequalities. Friends and family often facilitated recruitment; a finding replicated elsewhere (Cleland et al., 2018; Quirk and Haake, 2018). Aside from personal encouragement, Wiltshire and Stevinson (2018) note that volunteering labour, both given and received, binds participants to the event. Wiltshire and Stevinson (2018) go on to explain that social capital also influences field- 
specific cultural capital (Bourdieu, 1986). Parkrun has become a space in which knowledge of running performance, health and injury is disseminated, uniting the group through a shared understanding of how to manage the body. In conclusion, they suggest that public health interventions should focus on building social capital, which they contend is under-valued in neoliberal economies. We are sympathetic to the position Wiltshire and Stevinson (2018) take, and we share their belief that an increase in social capital can stimulate and facilitate changes in physical activity behaviours. We argue that parkrun communities may well be a source of social capital for some, yet the very community feel of parkrun may actually exclude some individuals.

Research has also explored the meanings that people attach to their parkrun participation. Wiltshire, Fullagar and Stevinson (2018) consider parkrun to be a health practice that facilitates 'collective bodywork', suggesting that the event provides an inclusive environment where individual 'body projects' (Shilling, 1993) in effect become collective achievements. A similar understanding of the event is proposed by Hindley (2018), who notes the importance of shared experiences of exercising together. Focusing on identity, Wiltshire et al. (2018) suggest that a plurality of 'subject positions' (p11) allow for the sharing of space by multiple types of parkrunner. Fundamentally, the authors argue that the non-runner can become a parkrunner and then a runner, a change in subjectivity that may facilitate a change in physical activity levels.

Hindley $(2018$, p6) refers to parkrun as a 'community-based recreational running initiative'. In defining this group, Hindley $(2018$, p13) suggests that 'parkrunners belong to an identifiable group with its own norms, values, behaviours and language'. Hindley (2018) points to the wearing of t-shirts that denote how many parkruns a runner has completed as an example of this shared identity. The importance of this shared identity was researched by Stevens, Rees and Polman (2019), who adopt psychology's social identity approach which 
questioned whether group identities have been internalised by an individual. Their research explores how identification with parkrun groups may impact on parkrun participation and experience, as well as group cohesion and life satisfaction. Stevens et al. (2019) note that statistically significant correlations could be found between strength of identification with parkrun and level of participation, 'positive exercise experiences' (p222) and group cohesion, but not for life satisfaction.

In summary, media and research accounts present parkrun as a 'community' which may potentially yield public health benefits. Community is often put forward as a self-evident description of people coming together. However, how precisely does this community function in contemporary society? We agree with Wiltshire and Stevinson $(2018, \mathrm{p} 49)$ when they state that we need social theory to "capture the complexity that is integral to our understanding of the social world'. To this end, we contend that the social theories of Emile Durkheim can enrich our understanding of the parkrun community. Understanding community in parkrun is key because it helps us bring to light; 1) how community facilitate or hinder sustained changes to physical activity behaviours and 2) how parkrun communities could change to provide a more efficacious environment for physical activity behaviour change.

\section{Durkheim and community}

\section{Solidarity}

At the heart of Emile Durkheim's work is an analysis of the shifting social relations caused by processes of modernity that disrupt the traditional relationship between individual and society. In The Division of Labour (1984[1893]) Durkheim suggests that traditional societies had a holistic approach to morals and values, leading to a 'conscience collective' that is allencompassing and 'religious in nature' (Giddens, 1972). Durkheim (1984[1893], p61) refers 
to these societies as being based upon mechanical solidarity, a solidarity 'deriving from resemblances, [that] binds the individual to society'. Resemblances here may be geographical/spatial, class based/occupational, religious, ethnic or cultural with such similarities creating a shared worldview and moral framework. Traditional societies, therefore, have solidarity that is based upon similarity, moral uniformity and shared values, cultures and traditions (Royce, 2015). For Durkheim, economic modernisation challenges the conscience collective of traditional societies. Modern society, to Durkheim, is categorised as replacing mechanical solidarity with organic solidarity characterised by an interlocking of different individual roles that leads to social cohesion. Organic solidarity binds people together through shared interest, rather than through kinship. Such forms of solidarity cut across spatial, class, gender and ethnic boundaries.

\section{Morality}

In explaining the interplay between individual and society, Durkheim (1973[1914]) believed in a homo duplex conception of man (sic): humanity torn between embodied urges, which must be curbed by the moral framework of wider society. The restraining of individual desires occurs within the institutions of the family, the church and the community, the breakdown of which is attributed to modernity. Yet, Durkheim's (1995[1893]) conception of organic solidarity suggests that the division of labour could replace the moral education of these institutions (Royce, 2015). The coming together of different economic interests would bind individuals together through interdependence, leading to a new moral code, one not based on the family or church.

In explaining this analysis, Durkheim (1995[1912]) explored the underlying social processes of religion to reveal how non-ecclesiastical settings could produce moral codes. In doing so, Durkheim (1912) details the role of rituals, which bestow upon objects or behaviours a sacredness. The sacred in religious beliefs relates to that which is 'the subject of special 
attitudes of awe and reverence', while the oppositional profane refers to 'mundane, everyday life' (Giddens, 1972, p25). Durkheim rejects an innate moralism and instead demonstrates how religious groups socially construct morality (Shilling and Mellor, 1997), a position that logically allows for the creation of a secular morality in the wake of secularisation.

Furthermore, Durkheim (1995[1912], p441) considers the enactment of and adherence to religious rituals as a process of becoming 'the sacred by the very act of leaving the profane'. Durkheim (1995[1912], p589) refers to these rituals as 'joyful feasts' but also 'sad celebrations', in that the ritual is not only about achieving a new sacred status but also about remembering a profane past. The ritual is the symbol of present sacred practices which have replaced previously mundane or immoral actions. Durkheim (1995[1912], p589) refers to these rituals as 'piacular' ceremonies, for they celebrate the overcoming of previous wrongdoings. These processes could also take place outside of religious settings.

\section{Collective Effervescence}

In explaining how religion, and community more broadly, takes on the task of moral education, Durkheim (1995[1912]) focuses on the process of 'collective effervescence'. He describes effervescence as the 'extraordinary powers that excite (participants) to the point of frenzy' (Durkheim, 1995[1912]). It represents a transcendental process whereby the individual becomes conscious of the larger collective and the social, setting aside individual desires. This 'collective energy or vitality’ (Royce, 2015, p184) reaffirms the community's value system and moral code. In Durkheim's (1995[1912], p303) words:

'There are periods in history when, under the influence of some great social upheaval, social interaction becomes much more frequent and active. Men seek each other's company and assemble together more often. The general effervescence results which is characteristic of revolutionary or creative epochs. Now this greater activity results in a general stimulation of individual forces. Men 
see more and differently than in normal times. The changes which occur are not merely limited and small-scale: men become other than themselves.'

Aside from revolutionary contexts, Durkheim (1995 [1912]) notes how the ritual meeting of groups leads to less aggressive outcomes of collective effervescence. He notes how political, economic and religious groups must repeatedly come together to 'strengthen sentiments which, if left to themselves, would soon weaken' (Durkheim, 1995[1912], p302). Durkheim's view of modernity is that these sentiments have weakened through the 'devitalisation' of society (Nisbet, 1993[1966]), that is, the reduction of emotional intensity within a society. Yet as Royce (2015) argues, Durkheim believed that organic solidarity would eventually lead to a revitalisation of society when the transition from traditional to modern society was complete.

Shilling and Mellor (1998) draw attention to Durkheim's ambivalence towards the consequences of collective effervescence. The outcomes can be positive or negative. As the above quote suggests, collective effervescence can lead to large-scale social disruption. It can, as Mestrovic (1994) warns, result in ethnic conflict through the effervescence of those bound by perceived and superficial similarities. In contrast, Durkheim's framing of collective effervescence often situates the process as leading towards the 'moral', which, as Field (1995) notes, is often synonymous with 'social' in Durkheim's work. As such, collective effervescence could lead to positive social outcomes through a new sociality. More recently, Maffesoli's (1996) work on 'neo-tribes' suggests that the collective effervescent experiences of smaller groups may offer protection against the 'cold winds of modernity and the alienating experience of the economic-political order' (Pickering, 2002, p7).

The work of Durkheim on solidarity, morality and collective effervescence can be a useful tool to understand parkrun. As Hindley (2018) has identified, the wearing of parkrun t-shirts and the regular participation in post-event routines could be seen as akin to religious practices. 
Furthermore, it can be argued that participation in parkrun is located historically within a contemporary neoliberal governmentality that situates physical activity as a moral and individual practice (Bercovitz, 2000; Dallaire et al., 2012; Lupton, 1997). The research and media focus on community also hints at the development of solidarity amongst participants. Therefore, a Durkheimian framework is appropriate in underpinning an exploration of how parkrun participants relate to their parkrun 'community'. These ideas also allow us to explore what values the community deems sacred and how individuals navigate any potential tension between their desires and the collective parkrun project. Such a framework also allows us to understand if parkrun contains any exclusionary forces.

\section{Methodology}

To explore the parkrun community, we draw upon a project that we were commissioned to undertake for Strava ${ }^{1}$. Instead of completing research in-house, Strava wanted an independent academic examination of the impact of its app on wellbeing and happiness amongst parkrunners. Strava allows for the uploading of physical activity data from GPS watches or smartphones. Parkrun and Strava had collaborated from 2014, from which point participants could align their online accounts. The researchers of this paper collaborated with the team from Strava to create survey questions. The researchers led this relationship, with Strava ensuring that the survey's length and nomenclature were appropriate. The nature of this relationship meant that the researchers could build upon previous academic research to inform the survey design of this study, facilitating comparison with existing literature.

Following ethical approval from Glasgow Caledonian University, thirty Strava-using parkrunners, known personally either to the researchers or our Strava contacts, completed a pilot survey and offered constructive feedback. The revised survey went live on February $18^{\text {th }}$,

\footnotetext{
${ }^{1}$ Strava is an online and app-based platform that allows users to track their physical activities via GPS units installed in smartphones, watches and other wearables.
} 
2018, when Strava emailed its UK users who had connected their Strava account to their parkrun account. We sent a reminder on February $24^{\text {th, }}$ before the survey closed a couple of weeks later on March $12^{\text {th }}$. No personal identifiers were collected, and the survey tool was configured to ensure that it did not record the IP address of respondents. An information sheet at the beginning of the survey ensured that consent to participate was fully informed.

Participants were informed of Strava's involvement in the research and were advised that findings would also be used for academic purposes. Any identifying material in qualitative data has been anonymised.

\section{Survey Tool}

After 22 days, we had received 8157 responses, with 7,271 respondents fully completing the questionnaire. To assess the representativeness of our sample, following our request, Strava provided population counts for age and gender (counts of men and women in five-year age bands) for all Strava-using parkrunners in the UK. We determined that our sample slightly over-represented men and those aged between 30 and 50 years old. To account for this we used the SPSS statistics package to weight our results by age and gender. We used grossingup weights to adjust the survey population to match the total population it represents (parkrunners registered with Strava) in terms of its combined age and gender profile. All data in this paper, refer to the weighted survey population, i.e. that which is representative of Strava-using parkrunners in the UK.

Most respondents came from England (85.7\%), which was proportionate to the general UK population distribution, with significant numbers of responses being returned from each of the UK's national regions. We asked participants how many parkruns they had completed . Most respondents had taken part in 11 to 49 parkruns, although over 2,000 participants reported that they had completed more than 50 parkruns (46.0\%). Most respondents were taking part in parkrun on at least a monthly basis $(76.5 \%)$, with over 2,300 participants 
reporting that they completed the event weekly (33.0\%). Over 5,000 respondents suggested they felt either a 'fairly' or 'very' strong sense of belonging to their local parkrun (71.2\%). Table 1 presents the full participant details.

(insert Table 1 about here)

\section{Open-Ended Questions}

At 23 different points our survey allowed respondents to propose an alternative answer to a question with fixed response options or encouraged them to provide additional information pertaining to the answer they selected. These qualitative responses are the primary source of data in this paper. Three of these open-ended-questions produced data on experiences of parkrun and reasons for participation.

Our first open-ended question was part of a multiple-response question that asked why participants took part in parkrun. Possible answers were: to maintain fitness (63.7\%); to get fitter (58.2\%); to meet up with people I know (45.6\%); to meet new people (26.2\%); to compete against my own times $(78.9 \%)$; to compete against others $(26.8 \%)$; to get out of the house (30.0\%); it's now a habit (43.3\%). Our ninth option was 'other', which allowed respondents to give a qualitative answer. This option was selected by 689 respondents, making up $9.5 \%$ of the sample.

We also asked participants to report on the strength of their attachment to their local parkrun. Possible answers included: very strongly (31.9\%); fairly strongly (39.3\%); not very strongly (18.3\%); not at all strongly (4.6\%); don't know (1.5\%). A follow-up question specifically asked participants to explain their previous answer. We found that 1,814 respondents $(22.2 \%$ of participants) offered a qualitative explanation that accounted for their attachment to parkrun. Most of these respondents had previously answered very strongly (42.6\%), with the remaining majority split across fairly strongly (26.1\%) not very strongly $(23.4 \%)$, not at all 
strong (6.0\%) and don't know (1.9\%). As such, most respondents who offered explanations had previously signalled a strong attachment to parkrun.

At the end of the survey, we asked participants if they wanted to add a comment relating to anything mentioned in the survey. At this point, 683 participants gave responses $(8.3 \%$ of respondents). Most of these were summarising statements about participation in parkrun and the use of Strava. For this reason, they have been included in this analysis.

\section{Data Analysis}

In total, 3,186 open-ended responses were analysed. The initial word count of the analysed data was 72,075 words. We have included quotes from 22 different participants, with no single participant providing more than one quote. Participant information for those quoted can be found in Table 2. We have used pseudonyms to preserve anonymity.

(insert table 2 about here)

Taking inspiration from Wiltshire and Stevinson's (2018) application of Bourdieusian social theory to understand the role of social capital in parkrun, our analysis followed Jackson and Mazzei's (2013) theory-driven approach to data analysis. Borrowing the phrase from Deleuze and Guattari (1987), Jackson and Mazzei (2013) call for a 'plugging in' of theory into a qualitative dataset. The process of 'plugging in' first entails a thorough reading of the data before the identification of relevant theorists that may be used to interpret the text. The initial reading of our data led to the identification of Durkheim's work on solidarity, morality and collective effervescence as an appropriate framework to make sense of our respondents' experiences.

Practically, data analysis followed a standard thematic analysis process whereby initial codes developed into elicited themes (Braun and Clarke, 2006). The analysis was predominantly undertaken by the first author, with second and third authors acting as peer corroborators who 
would constructively challenge the interpretations of the first author. Thematic analysis was initially inductive and led to themes that were then read through for familiarisation. We recognised the importance of ties to both local and non-local communities, cohesion within parkrun communities themselves, the community's values and the way in which parkrun brought together people with a wide variety of values and motivations. At this point appropriate social theories were considered before Emile Durkheim's writings on community and solidary were chosen. We also considered the social theories of Pierre Bourdieu and Michel Maffesoli, but concluded that the theories of Durkheim provided a stronger, more appropriate framework in this instance. In following the process detailed by Wiltshire and Stevinson (2018), a deductive analysis then allowed us to match existing themes to elements of Durkheim's theoretical framework. This process produced themes that led us to understand what makes a community through the lens of solidarity, morality and collective effervescence. In presenting such data we will first present each inductively derived theme followed by our application of a Durkheimian lens. We present our analysis in three themes relating to solidarity, morality and collective effervescence in parkrun as constituents of community.

\section{The parkrun community and solidarity}

Our first theme draws attention to how our research participants understood and constructed parkrun as a community. Three elements emerged: community as both local and non-local; cohesion; and volunteering.

\section{A local and non-local community}

The emotional attachment to the parkrun community was most often related to their local parkrun event. Just over one half of our sample (55.6\%) suggested that they most often participated in their local events but occasionally tried others. Just over one quarter $(27.3 \%)$ 
of respondents indicated that they only participated in their local parkrun. The attachment to the local parkrun was important for many participants:

As I have a 'home' parkrun, and a parkrun shirt with the 'home' course's name on it, I feel a strong link to my local parkrun. When I visit other parkruns, I feel like I'm representing my local course and inevitably I compare the other course to my 'home' course and find them wanting! I can always find a way to rationalise why my 'home' course is better - the venue is prettier; it's better because it's quicker; it's better because it's tougher (and therefore slower); the marshals are friendlier; the runners are friendlier to the marshals... and so on.

(Marc)

For many, like Marc, a feeling of attachment to a local parkrun presented itself as the face of community in parkrun. Others rejected the idea of feeling attached to their local parkrun, but instead noted the importance of the broader parkrun movement:

My 'local' parkrun is six miles away, and the core attendees live locally, and many are members of a local running club. I know no-one in this local area so do not really feel part of the 'local' parkrun community however I do feel part of the wider parkrun 'global' community.

(Nicole)

For Nicole, the parkrun community was not bound by local space, but instead occupied an imagined global space. Others noted how the parkrun network provided opportunities that extended far beyond the local. Multiple respondents detailed this accessibility in their accounts:

To be part of a free club that has its own kit is an amazing feeling. You can go anywhere in the country, or abroad and immediately connect with other 
likeminded people, even when it isn't a Saturday if you see someone wearing their 25 (volunteer), 50, 100, 250 or apricot top ${ }^{2}$ it connects you. Ultimately seeing someone away from home wearing an apricot top with your home parkrun is a great feeling. It allows for a conversation to be immediately struck up when the start of a running event normally results in people standing around on their own.

(Daniel)

Daniel's understanding of the parkrun community incorporates both local and non-local spaces. Indeed, his recognition of others who wear apricot tops with his home name can be seen as an example of mechanical solidarity, whereby resemblances between individuals, in this case home parkrun, present as a symbol of parkrun's local community. Aside from the ritual wearing of clothing, Daniel's insistence on other parkrunners as 'likeminded' is another way in which similarity within the parkrun community is understood. As such the parkrunner is profiled as having a particular personality, or shared worldview, which binds together people from around the country and beyond.

\section{Community Cohesion}

As previous research has demonstrated (Stevinson et al., 2015), the sociability and inclusivity of parkrun was a big draw to the event. The race directors, volunteers, marshals and other athletes were all actors that helped create this environment:

I lived across the road from parkrun and kept wimping out of participating. Then a Twitter acquaintance offered to take me for a walk around the course to reassure me it wasn't that scary. A week later, I arrived at parkrun and randomly

\footnotetext{
${ }^{2}$ Apricot tops are the official line of clothing developed by parkrun and sold officially via retailer Pro:Direct Running
} 
introduced myself to some other people who I continue to look out for and talk to each week. I've since also moved in with the man who took me for that walk.

Other parkrunners have occasionally run the route with me to give me advice and encouragement about improving my running, and I've been invited to numerous social events by the different people I've met. I occasionally volunteer, which has introduced me to even more people, and I (we) often join an assorted group of other parkrunners in the park

(Philippa)

Philippa's comment details how entrance into the parkrun community can lead to the creation of sub-communities - presented in her account as an 'assorted group'. For some this was an issue, with terms such as cliques being used to describe some of marginalising elements of parkruns' community. Numerous participants suggested that the inclusivity and 'feel' ${ }^{3}$ of the parkrun community had changed as the event had grown. A few participants suggested that their parkrun venue and course were now less well suited to the event, on account of limited parking provision or course form (those involving narrow paths or multiple laps). Others were less focused in their critique and focused more on the size, ownership and intimacy of their events:

First few years it was very much a strong belonging to the local parkrun community, however as the event has grown (approx 3-fold) in the five years, it has become a little more anonymous.

(Sandra)

For first two or three years, I felt very strongly attached to my local parkrun, but as numbers swelled there I ventured to other venues and found I enjoyed running

\footnotetext{
${ }^{3}$ The word 'feel' was used 665 times, with the majority of these relating to community or feelings of being welcomed.
} 
elsewhere too. I continued to volunteer at my home parkrun however until an unfortunate incident, when a runner was very rude to me and upset me greatly, and am now volunteering elsewhere too. So, my links to my local parkrun have in fact very much lessened over time.

(Maureen)

My original parkrun had to relocate, as it was outgrowing the capacity of the location to cope with the number of cars. It was tough to get the courage up to go in the first place but the course was lovely and the people seemed really nice. Then the parkrun moved - but didn't seem to bring the more inclusive feel with it. It now seems to be a real racing parkrun. Irrespective of where you parkrun, if there are loops, you're going to be lapped. Fine. What I don't think is fine is feeling like you're in the way, or that you're stopping people getting away on time - certainly a comment I heard whilst volunteering one week ugh, yeah, we've got another 10-20 minutes yet waiting for the last ones. I'd rather not feel like I'm holding people up!

(Alice)

While a significant minority had voiced concerns over the growth of their parkruns, only $22.9 \%$ of respondents said they felt either 'not very strong' or 'not at all' attachment to their local parkrun. The sense of community is therefore widespread, but the growth of the phenomenon poses challenges to solidarity within the community.

\section{Volunteering}

Some of the key actors in the creation of parkrun communities were volunteers. These individuals ensured the events ran smoothly. The role of volunteer is somewhat fluid, with individuals alternating between participating in the events some weeks and volunteerring in 
others. Several respondents suggested that volunteering would be a way of remaining within the community during times of injury:

I have loved parkrun since I did the first parkrun in Cartmel and unless I am injured, when I would volunteer instead, it is part of my weekend which I look forward to enormously. Over the years I have met loads of new people and just love how it doesn't matter if you are the fastest parkrunner or do it for the firsttime walking. Everyone is equal no matter your age or ability. Just love, love parkrun. I hope it goes on forever.

(Janice)

Janice's account stresses the appeal of parkrun to people with little in the way of similarity when it comes to running ability or age. As such, volunteers often stressed inclusive elements of parkrun and presented their work as for everyone, irrespective of difference. Others rationalised their volunteering as support for local activities, daughters, husbands, wives, others taking part and the broader parkrun ethos. Some respondents positioned the support of children as part of responsible parenthood that would demonstrate the importance of physical activity and the development of responsible citizenship:

Parkrun has encouraged me to encourage my children to exercise...am excited at the prospect of a junior parkrun coming soon to our area. From not really knowing anyone at my first parkrun in 2016, I tentatively volunteered to marshal in early 2017, and now find myself as part of the core team, primarily managing our DofE (Duke of Edinburgh) volunteers but also helping out with lots of other roles. Today I did Results Processing for the first time and was also the far less rewarding car park signage person- freeeeezing fingers! It has become a really important part of my life and family life. Belonging sets a brilliant example to my 
daughters - not only around fitness but also around the joy of volunteering if you find something you really love to do. My 12-year-old is now part of the core team too and is putting in a bid to be Run Director one week, and taking Paul SintonHewitt's (Founder of parkrun) job soon after that.

(Karen)

Setting a positive example to children, and being a responsible citizen, are motivations beyond engagement in physical activity.Together with extoling the merits of volunteering, these demonstrate the multi-dimensional nature of parkrun's motives. From a Durkheimian perspective the above quotes demonstrate differences within the parkrun community and should be interpreted as a form of organic solidarity that brings together a wide range of individuals, who use the event for different purposes. It is to this variation we now turn.

\section{Motives for entering the parkrun community as morality}

In this theme we explore health and body projects as well as how relationships unfold within parkrun. We understand these two areas to be elements of a secular morality. These emerged when we explored the reasons why people participate, highlighting various vocabularies of motive (Mills, 1940). Within our survey, we asked participants why they took part in parkrun. Multiple options were given, with the majority reporting that maintaining $(63.7 \%)$ or improving (58.2\%) fitness was a factor. The most significant factor related to competing against oneself (78.9\%), while 'meeting people I know' (45.5\%), 'meeting new people' $(26.2 \%)$ and 'competing against others' $(26.8 \%)$ were all minority experiences.

\section{Health and Body Projects}

Aside from maintaining or improving fitness, participants freely expressed a range of other health-related motives. Many participants framed their 'getting fit' alongside managing the 
body. These body projects were verbalised as either losing weight or controlling it, with some detailing this rationale through extended accounts:

I have in the past suffered with anxiety. My friend was talking about parkrun one day so the next week, the 18 stone Frank Smith also talked the wife into going too. 12 months on and a PB of 23.25, and with 5 10k runs under my belt and 2 half marathons booked for 2018 and the family dog is now a member of [names parkrun] community as a tail walker and we are all loving it. I'm now 13 1/2 stone and less than 12 months later myself and the wife are now members of [names club] running club and loving it. As for the anxiety, well that only occurs when I can't go running with the most amazing people I've ever met, the running community $^{4}$

$(\mathrm{Scott})$

I cannot understate the impact parkrun has had on my running journey. I initially took part in parkrun to lose weight after my regular 5 a side football booking ended. I tried it a few times and never gave it much thought about how good it would be. I was befriended by a number of runners who happened to run in a local running club, and from there I took my running more seriously. As I often tell the story I was 18 stone and 9 pounds on my first parkrun .... I used parkrun as a catalyst to lose weight, and as of now I am at 16 stone and 2 pounds. The pictures of me taking part in previous parkruns show how much weight I have lost (around face/belly).

(Martin)

\footnotetext{
${ }^{4}$ The parkrun destinations, times and names have all been changed to protect the identity of the respondent
} 
Some respondents presented the initial desire to lose weight alongside getting fitter.

Transformation stories verbalised the impact of this approach. It became clear that the initial rationale for parkrunning had developed into different meaning structures. Losing weight may have provided a stimulus to begin, but new motives had led to a maintained engagement with parkrun:

Just over 2 years ago used to watch \& support daughter at races. Decided to try running to get fitter/ lose weight. Started couch to $5 \mathrm{k}$ with no fitness at all - out of breath running 100 Metres. First proper organised running event was a parkrun as non-judgemental and not scary for a fat middle-aged woman. Loved it ... carried on attending then friend mentioned Strava. Tried it \& loved it if embarrassed by my super slow running. Followed someone from local parkrun - got talking on Strava; few months later she joined a running club - I contacted her for info result I joined the same club. A brilliant, supportive group of people. More parkruns/ local events/ more Strava contacts from local events (but not just for the sake of numbers). Made friends, got faster, got fitter. Parkrun is simply brilliant, supportive, inclusive, I could go on. Parkrun and Strava: intrinsically linked with my journey from unfit \& fat to where I am now; 4 stone lighter \& running up to half marathons.

As many of the snapshots above demonstrate, participants mobilise personal stories about themselves that locate parkrun as a positive ritual that contrasts to a negative past. Following Durkheim, engaging in parkrun can be understood as a piacular celebration: a positive ceremony that stands to symbolise the leaving behind of negative histories. These piacular celebrations may be personal - as in individuals celebrating their leaving behind of the past or social - as in the renewal of community at a time when communities are widely regarded 
to have dwindled. For those who narrated transformative stories of weight loss or health improvement, parkrun provides a weekly ritual that celebrates the continued escape from the past.

Another recurring theme was that the early Saturday start that parkrun provided had a deterrent effect on health behaviours deemed detrimental that could occur the night before:

I also have found that parkrun benefits me in this very simple way: because I have parkrun on Saturday morning, it motivates me not to eat poorly or drink too much on a Friday night. It also helps running because it motivates you to run more through the week so you can improve your time. It really is an amazingly deceptive (in a good way...) way of getting people to enjoy running!

(Jonny)

Parkrun changed my life. It gave me the confidence to do exercise that I never had before and has changed many other things too, e.g. I no longer drink alcohol on a Friday night.

(Lewis)

From a Durkheimian perspective, parkrun acted as a deterrent to behaviours that were situated as undesirable (drinking to excess, eating poorly). Such behaviours have, in a variety of religious doctrines, long been presented as immoral, but in contemporary neoliberal societies, where health has become an individual responsibility, the disciplining of such habits is a moral act. Indeed, others have argued that sport and physical activity have become moral practices (Zanker and Gard, 2008). Aside from morality surrounding health, other sources of moral worth were denoted to emanate from parkrun. 


\section{Relationships and parkrun}

Aside from deterring the excesses of a Friday night, parkrun was framed as improving relationships between individuals, their families and communities. There were various claims that parkrun had been the birthplace of romances (as noted previously) and two accounts detailed how weddings had become entangled with parkrun communities. Less exceptionally, many engaged in parkrun to support a spouse or simply as a familial activity:

Parkrun has been amazing for my whole family! My husband started going, and I would watch in the kids' park with my daughter. A year later I had a baby and then did a $0-5 \mathrm{k}$ programme with a local running club due to park run inspiration. My first park run was during the programme running for 2 minutes and walking for 1 minute which was in October/ November time and since then I have got quicker, stronger, healthier, happier and am now running further distances during the week with a local club up to 10k. My 4-year-old has participated in the local Junior park run and loves watching us run past the kids park on a Saturday cheering us on. There is then all the people we have met through it who we now meet in the cafe afterwards with to socialise, cheer each other on throughout the run as everyone is at different speeds and abilities, our children have made friends. Parkrun has become a family, from all the volunteers to the other runners to the people who work at our country park it is held at, it is amazing! I never thought I would be a runner and now I love it and am truly sad if I cannot make parkrun one week!

(Stephanie)

Others felt as if their participation was a contribution to the local community, with one respondent claiming it's 'heart-warming to see such a great community in action'. When the community was mentioned as a rationale for competing, it was often mentioned alongside 
volunteering, which itself was an often-cited rationale for taking part. Participants framed volunteering as a process of giving back to the community. The act of volunteering was a cornerstone of the community's inclusivity, as described by one respondent:

My parkrun is a very inclusive, friendly community. Random strangers have helped me when I started running and was very slow, they are friends now. They have actively encouraged my daughter (under 11) who was very slow but has cut about 10 minutes off her $5 \mathrm{k}$ time - she likes to go regularly because she feels welcome and appreciated and encouraged. We try to give back by volunteering, and people show their appreciation for this as well.

(Aaron)

The role of parkrun in generating community and aiding relationships both within and outwith the family gives parkrun a sacred quality. Applying a Durkheimian perspective, parkrun may provide a sacred space for the reproduction of the community and the family, with the event acting as a regular ritual that breaks up the profane nature of everyday existence. Indeed, various participants conferred on parkrun a special quality, signifying its sacredness through its ability to produce effervescent moments.

\section{Collective effervescence in Parkrun: Values, Ethos and Buzz}

In identifying with their parkrun community, respondents often referred to the ethos and values of parkrun. It was never explicitly stated what the parkrun ethos was, but respondents provided a variety of different understandings. Some participants suggested that the ethos of parkrun was really about providing a space for challenging the self. Indeed, the most popular quantitative answer for why people participated in parkrun was to compete against the self (78.9\%). One qualitative example explains that challenging the self is something everyone can aspire to: 
I agree with the ethos of parkrun, I love to challenge myself, it's a great way to encourage those who do not see themselves as runners to exercise and challenge themselves, and most of all I love the rare occasions when I manage to get my whole family to run parkrun as a family (though not necessarily sticking together to the finish).

(Frank)

Alongside the ethos and values of parkrun, many suggested that the event brought people closer together and developed a community spirit. Various qualitative responses explained this 'spirit':

I know lots of people at my local parkrun, and this fosters a spirit [our emphasis] of community as we are all there for each other and support each other with our running and chat about anything and generally have a lot of fun.

(Steve)

Love the social and community spirit (our emphasis) of it - you feel like you're part of something larger than just a run. The encouragement from others has aided me loads in growing in confidence and fitness - both mental and physical

(Darren)

These feelings of community spirit appear to create an emotional reaction within many respondents. Participating in parkrun wasn't merely about turning up to run $5 \mathrm{~km}$; it was about experiencing 'the buzz':

Running in an event like parkrun is completely different to running on your own. Whilst both are good in different ways, the sense of community and the buzz of a parkrun (even though I go alone) is what is so enjoyable 
Both Strava and parkrun are really positive things for me. I always get a buzz from going to a parkrun and feel like part of a community of people who are 'up for anything' and raring to go on a Saturday morning.

(Katie)

Thus feelings of community emanate from this coming together of individuals who in effect commune together in this secular space. The 'buzz' can be understood as a verbalised expression of collective effervescence, which draws individuals into a continual relationship with parkrun. It connects individuals to an imagined community that extends beyond the locale of each individual parkrun. Indeed, Darren explicitly comments on how parkrun adjoins him to 'something larger than just a run'.

\section{Conclusion}

Our analysis enables us to conclude that parkrun could indeed be understood as community, underpinned by organic solidarity. This is evidenced by the findngs that many participants feel attachment to their 'home' parkrun but also to what they identify as the parkrun 'ethos' which transcends geographical boundaries. This flexible attachment is fuelled by recognition of being part of something bigger than oneself and by connecting with others who are seen as likeminded. Cohesion is thus an effect of community-making, a process to which runners, race directors and volunteers all contribute.

Whilst the motives for signing up to parkrun are varied, they relate to individual and social anxieties about the body and its appropriate management (weight control, excessive alcohol consumption, physical inactivity, etc). Thus, a cross-section of parkrunners are united in the desire to achieve an ascetic, moral orientation to life which is compensated by enhanced personal relationships and effervescent emotional responses. Parkrun is therefore a space for 
secular communion: individual projects are in accordance and become subsumed under a collective project of physical and mental health improvement.

Parkrun also speaks to broader anxieties about late modernity, globalisation and 'broken communities' (Savage 2013). As such, participants present parkrun as a virtuous space in a discursive context that understands contemporary Britain to be an anomic society (Durkheim, 1893). Taking part in physical activity is a performance of responsible citizenship, which, combined with the renewal of community, creates a sacred environment.

Having said that, we align with Durkheim in our ambivalence towards this collective force (Shilling and Mellor, 1996). Parkrun's role in generating inclusive and active communities is, we would argue, vulnerable. As parkrun has grown, many participants have struggled to maintain their attachment to their local parkrun community. Many participants suggested that the growing popularity of parkrun had diminished their sense of belonging to the group. We also found that several people suggested that cliques prevailed at their local parkrun, making it less likely for them, being outside the clique, to feel part of its community. Others suggested that in being a slower runner, they often felt ignored by many other parkrunners who had left before they had finished, or, in some cases, had thought that they were a burden, particularly in those parkruns that involved multiple laps of the same circuit. Thus the collective effervescence of some in the group may appear to be exclusionary to others. If individuals are excluded from the effervescence of the core group, the risk here is that continued participation may be compromised for those for whom 'community feel' is at least as important as athletic performance. Using Durkheim's theoretical and conceptual toolkit has enabled us to enhance existing research that focuses on parkrun as a community. We extend this work by examining the processes which generate this 'community feel', but also by connecting the community-making processes to wider societal anxieties about both anomie and physical inactivity. To conclude, it is clear that parkrun can indeed make an 
important contribution to increasing physical activity participation by invoking community but its success rests on an acceptance of physical activity participation as a collective responsibility.

The insights presented here were drawn from the accounts of a subset of parkrun participants, that is Strava users who had linked their two accounts. We are aware that their characteristics, experiences and willingness to account for their experiences might not reflect those of non Strava affiliated parkrun participants. Future research could therefore interrogate the ways in which community is constructed and experienced among other parkrun participants. In addition, as this study was largely based on responses from open-ended survey questions, future research could use more intensive qualitative approaches (such as in-depth interviews and ethnography) to explore in greater depth subjective parkrun community experiences.

\section{Acknowledgements}

We wish to thank the parkrunners who participated in our survey, Gareth Mills at Strava, and Andy Baddeley at Fusion Media.

\section{References}

Bercovitz, K.L (2000) A critical analysis of Canada's 'Active Living': science of politics? Critical Public Health, 10(1), 19-39.

Braun, V., \& Clarke, V. (2006). Using thematic analysis in psychology. Qualitative Research in Psychology, 3(2), 77-101.

Bourdieu, P. (1986). The forms of capital. In: D. Richardson, ed. Handbook of Theory and Research for the Sociology of Education. New York, NY: Greenwood, 241-258.

Chakrabortty, A (2018, $28^{\text {th }}$ August) Forget Profit. It's love and fun that drive innovations like Parkrun. The Guardian. Retrieved from:

https://www.theguardian.com/commentisfree/2018/aug/29/forget-profit-love-funinnovation-parkrun 
Cleland, V., Nash, M., Sharman, M. J., \& Claflin, S. (2019). Exploring the Health-Promoting Potential of the " parkrun" Phenomenon: What Factors are Associated With Higher Levels of Participation? American Journal of Health Promotion. 33(1). 13-23.

Dallaire, C., Lemyre, L., Krewski, D., \& Gibbs, L. B. (2012). The gap between knowing and doing: how Canadians understand physical activity as a health risk management strategy. Sociology of Sport Journal, 29(3), 325-347.

Darby, N. (2016, $13^{\text {th }}$ April) Why charging parkrun is a terrible idea. The Guardian. Retrieved from: https://www.theguardian.com/lifeandstyle/the-runningblog/2016/apr/13/why-charging-for-parkrun-is-a-terrible-idea

Deleuze, G. \& Guattari, F. (1987) A Thousand Plateaus, trans. Brian Massumi, Minneapolis: University of Minnesota Press.

Dickenson, J. (2018, 11th June) Parkrun \& the NHS: a mutual cause for celebration. The Guardian. Retrieved from: https://www.theguardian.com/lifeandstyle/the-runningblog/2018/jun/11/parkrun-the-nhs-a-mutual-cause-for-celebration

Durkheim, E. (1973[1914]) The dualism of human nature and its social conditions. In R.N Bellah (eds) Emile Durkheim on Morality and Society, Chicago: University of Chicago Press.

Durkheim, E. (1984[1893]) The Division of Labour in Society, London: McMillan.

Durkheim, E. (1995[1912]) The Elementary Forms of Religious Life, New York: The Free Press.

Giddens, A. (1972). Emile Durkheim: Selected writings. Cambridge: Cambridge University Press.

Grunseit, A., Richards, J., \& Merom, D. (2018). Running on a High: parkrun and personal well-being. BMC Public Health, 18: Article 59.

Hindley, D. (2020). "More Than Just a Run in the Park": An Exploration of Parkrun as a Shared Leisure Space " More Than Just a Run in the Park": An Exploration of Parkrun as a Shared Leisure Space. Leisure Sciences, 42(1) 85-105.

Ingle, S (2018, $1^{\text {st }}$ October) How parkrun's 13 became 5 million and changed weekends forever. The Guardian. Retrieved from: https://www.theguardian.com/sport/blog/2018/oct/01/parkrun-five-mlllion-runners

Jackson, A. Y., \& Mazzei, L. A. (2013). Plugging one text into another: Thinking with theory in qualitative research. Qualitative Inquiry, 19(4), 261-271.

Lupton, D. (1997). The Imperative of Health: Public health and the regulated body. London, UK: Sage Publications.

Maffesoli, M. (1996) The Time of the Tribes London: Sage.

Mestrovic, S (1994) The Balkanisation of the West, London: Routledge.

Mills, C. W. (1940). Situated Actions and Vocabularies of Motive. American Sociological Review, 5(6), 904-913.

Morris, P., \& Scott, H. (2019). Not just a run in the park : a qualitative exploration of parkrun and mental health and mental health. Advances in Mental Health, 17(2)110-123.

Nisbet, R. (1993[1966]) The Sociological Tradition, Heinemann: London.

Parkrun (2019) parkrun UK Retrieved from: https://www.parkrun.org.uk/ 
Pickering, W, S, F (2002) Durkheim Today, Oxford: Berghahn.

Quirk, H., \& Haake, S. (2018). Interim evaluation results from the parkrun PROVE project. Journal of Physical Activity \& Health 15(10), 100.

Reece, L. J., Quirk, H., Wellington, C., Haake, S. J., \& Wilson, F. (2018). Bright Spots, physical activity investments that work: Parkrun; a global initiative striving for healthier and happier communities. British Journal of Sport Medicine 53 326-327.

Royce, E. (2015). Classical Social Theory and Modern Society: Marx, Durkheim, Weber. Rowman \& Littlefield.

Savage, M. (2013). Broken communities?. In Atkinson, W, Roberts, S and Savage, M (eds.) Class Inequality in Austerity Britain, pp. 145-162. Palgrave Macmillan, London.

Sharman, M.J., Nash, M, and Cleland, V (2019). Health and broader community benefit of parkrun - An exploratory qualitative study', Health Promotion Journal Australia, $30(2), 163-171$.

Shilling, C. (1993). The Body and Social Theory. London: Sage.

Shilling, C., \& Mellor, P. A. (1998). Durkheim, morality and modernity: collective effervescence, homo duplex and the sources of moral action. British Journal of Sociology, 49(2), 193-209.

Stevens, M., Rees, T., \& Polman, R. (2019). Social identification, exercise participation, and positive exercise experiences : Evidence from parkrun Social identification, exercise participation, and positive exercise experiences : Evidence from parkrun. Journal of Sports Sciences, 37(2), 221-228.

Stevinson, C, \& Hickson, M. (2013). Exploring the public health potential of a mass community participation event. Journal of Public Health, 36(2), 268-274.

Stevinson, C, \& Hickson, M. (2018). Changes in physical activity, weight and wellbeing outcomes among attendees of a weekly mass participation event: a prospective 12month study. Journal of Public Health, 41(4), 807-814.

Stevinson, C, Wiltshire, G., \& Hickson, M. (2015). Facilitating Participation in HealthEnhancing Physical Activity: A Qualitative Study of parkrun. International Journal of Behavioral Medicine, 22(2), 170-177.

Wiltshire, G. R., Fullagar, S., \& Stevinson, C. (2018). Exploring parkrun as a social context for collective health practices: running with and against the moral imperatives of health responsibilisation. Sociology of Health and Illness, 40(1), 3-17.

Wiltshire, G., \& Stevinson, C. (2018). Exploring the role of social capital in communitybased physical activity: qualitative insights from parkrun. Qualitative Research in Sport, Exercise and Health, 10(1), 47-62.

Zanker, C., \& Gard, M. (2008). Fatness, fitness, and the moral universe of sport and physical activity. Sociology of Sport Journal, 25(1), 48-65. 
Table 1 - Participant Characteristics, by Gender

\begin{tabular}{|c|c|c|c|c|}
\hline & & \multirow{2}{*}{\multicolumn{2}{|c|}{$\begin{array}{c}\text { Row percentages } \\
\text { Gender }\end{array}$}} & \multirow[b]{3}{*}{ Cases } \\
\hline & & & & \\
\hline & & Men & Women & \\
\hline \multirow[t]{4}{*}{ Age } & Under 30 & $55.8 \%$ & $44.2 \%$ & 1578 \\
\hline & $30 \mathrm{~s}$ & $59.7 \%$ & $40.3 \%$ & 2595 \\
\hline & $40 \mathrm{~s}$ & $61.9 \%$ & $38.1 \%$ & 2184 \\
\hline & 50 and over & $66.6 \%$ & $33.4 \%$ & 913 \\
\hline \multirow[t]{4}{*}{ UK National Region } & England & $60.8 \%$ & $39.2 \%$ & 6228 \\
\hline & Scotland & $58.4 \%$ & $41.6 \%$ & 517 \\
\hline & Wales & $53.7 \%$ & $46.3 \%$ & 315 \\
\hline & Northern Ireland & $59.6 \%$ & $40.4 \%$ & 136 \\
\hline \multirow[t]{5}{*}{ Number of complete parkruns } & Fewer than 10 & $54.8 \%$ & $45.2 \%$ & 1565 \\
\hline & Between 11 and 49 & $60.3 \%$ & $39.7 \%$ & 3339 \\
\hline & Between 50 and 99 & $60.9 \%$ & $39.1 \%$ & 1397 \\
\hline & Between 100 and 249 & $68.4 \%$ & $31.6 \%$ & 885 \\
\hline & 250 or more & $63.6 \%$ & $36.4 \%$ & 66 \\
\hline \multirow{4}{*}{$\begin{array}{l}\text { How strongly do you feel that you } \\
\text { belong to your local parkrun? }\end{array}$} & Very strongly & $57.4 \%$ & $42.6 \%$ & 2149 \\
\hline & Fairly strongly & $60.9 \%$ & $39.1 \%$ & 3084 \\
\hline & Not very strongly & $63.6 \%$ & $36.4 \%$ & 1535 \\
\hline & Not at all strongly & $63.0 \%$ & $37.0 \%$ & 370 \\
\hline \multirow{3}{*}{$\begin{array}{l}\text { How often do you complete } \\
\text { parkrun? }\end{array}$} & Every week & $59.1 \%$ & $40.9 \%$ & 2301 \\
\hline & Fortnightly to monthly & $60.7 \%$ & $39.3 \%$ & 3031 \\
\hline & Less than monthly & $62.2 \%$ & $37.8 \%$ & 1640 \\
\hline
\end{tabular}


Table 2 - Quoted Participant information

\begin{tabular}{|c|c|c|c|c|c|}
\hline $\begin{array}{l}\text { Participant } \\
\text { pseudonym }\end{array}$ & Gender & Age & $\begin{array}{l}\text { Time since first } \\
\text { parkrun }\end{array}$ & $\begin{array}{l}\text { Participation } \\
\text { frequency }\end{array}$ & $\begin{array}{l}\text { Number of parkruns } \\
\text { completed }\end{array}$ \\
\hline Frank & Male & $55-59$ & more than 5 years & few times a year & $50-99$ \\
\hline Steve & Male & $50-54$ & $\begin{array}{l}\text { between } 2 \text { and } 5 \\
\text { years }\end{array}$ & every week & $50-99$ \\
\hline Darren & Male & $40-44$ & $\begin{array}{l}\text { between } 2 \text { and } 5 \\
\text { years }\end{array}$ & every week & $50-99$ \\
\hline Paula & Female & $25-29$ & $\begin{array}{l}\text { between } 1 \text { and } 2 \\
\text { years }\end{array}$ & $\begin{array}{l}\text { once every other } \\
\text { month }\end{array}$ & $11-49$ \\
\hline Katie & Female & $20-24$ & $\begin{array}{l}\text { between } 2 \text { and } 5 \\
\text { years }\end{array}$ & few times a year & less than 10 \\
\hline Marc & Male & $30-34$ & $\begin{array}{l}\text { between } 2 \text { and } 5 \\
\text { years }\end{array}$ & every fortnight & $50-99$ \\
\hline Nicole & Female & $55-59$ & $\begin{array}{l}\text { between } 2 \text { and } 5 \\
\text { years }\end{array}$ & every month & $11-49$ \\
\hline Daniel & Male & $25-29$ & $\begin{array}{l}\text { between } 1 \text { and } 2 \\
\text { years }\end{array}$ & every fortnight & $50-99$ \\
\hline Philippa & Female & $35-39$ & $\begin{array}{l}\text { between } 1 \text { and } 2 \\
\text { years }\end{array}$ & every week & $50-99$ \\
\hline Sandra & Female & $35-39$ & $\begin{array}{l}\text { between } 2 \text { and } 5 \\
\text { years }\end{array}$ & every week & $100-249$ \\
\hline Maureen & Female & $55-59$ & more than 5 years & every week & $50-99$ \\
\hline Alice & Female & $40-44$ & $\begin{array}{l}\text { Between } 1 \text { and } 2 \\
\text { years }\end{array}$ & every week & $11-49$ \\
\hline Scott & Male & $40-44$ & $\begin{array}{l}\text { between } 1 \text { and } 2 \\
\text { years }\end{array}$ & every fortnight & $11-49$ \\
\hline Martin & Male & $35-39$ & $\begin{array}{l}\text { between } 2 \text { and } 5 \\
\text { years }\end{array}$ & $\begin{array}{l}\text { when not } \\
\text { participated in club } \\
\text { races }\end{array}$ & $50-99$ \\
\hline Lynne & Female & $50-54$ & $\begin{array}{l}\text { between } 1 \text { and } 2 \\
\text { years }\end{array}$ & every week & $50-99$ \\
\hline Jonny & Male & $25-29$ & $\begin{array}{l}\text { between } 1 \text { and } 2 \\
\text { years }\end{array}$ & every week & $11-49$ \\
\hline Lewis & Male & $35-39$ & $\begin{array}{l}\text { between } 2 \text { and } 5 \\
\text { years }\end{array}$ & every week & $50-99$ \\
\hline Stephanie & Female & $30-34$ & less than 6 months & $\begin{array}{l}\text { I do every Saturday I } \\
\text { am not working }\end{array}$ & $11-49$ \\
\hline Aaron & Male & $45-49$ & $\begin{array}{l}\text { between } 2 \text { and } 5 \\
\text { years }\end{array}$ & a few times a year & $11-49$ \\
\hline Janice & Female & $65+$ & more than 5 years & every week & $100-249$ \\
\hline Karen & Female & $40-44$ & $\begin{array}{l}\text { between } 1 \text { and } 2 \\
\text { years }\end{array}$ & every week & $50-99$ \\
\hline
\end{tabular}

